\title{
Proteolytic profiling and comparative analyses of active trypsin-like serine peptidases in preimaginal stages of Culex quinquefasciatus
}

Andre Borges-Veloso ${ }^{1}$, Leonardo Saboia-Vahia ${ }^{1}$, Patricia Cuervo ${ }^{2}$, Renata C Pires ${ }^{3}$, Constança Britto ${ }^{1}$, Nilma Fernandes ${ }^{4}$, Claudia M d'Avila-Levy ${ }^{1}$ and Jose B De Jesus ${ }^{1,4^{*}}$

\begin{abstract}
Background: The mosquito Culex quinquefasciatus, a widespread insect in tropical and sub-tropical regions of the world, is a vector of multiple arboviruses and parasites, and is considered an important risk to human and veterinary health. Proteolytic enzymes play crucial roles in the insect physiology including the modulation of embryonic development and food digestion. Therefore, these enzymes represent important targets for the development of new control strategies. This study presents zymographic characterization and comparative analysis of the proteolytic activity found in eggs, larval instars and pupae of Culex quinquefasciatus.

Methods: The proteolytic profiles of eggs, larvae and pupa of $C X$. quinquefasciatus were characterized by SDS-PAGE co-polymerized with $0.1 \%$ gelatin, according to the $\mathrm{pH}$, temperature and peptidase inhibitor sensitivity. In addition, the proteolytic activities were characterized in solution using $100 \mu \mathrm{M}$ of the fluorogenic substrate Z-Phe-Arg-AMC.

Results: Comparison of the proteolytic profiles by substrate-SDS-PAGE from all preimaginal stages of the insect revealed qualitative and quantitative differences in the peptidase expression among eggs, larvae and pupae. Use of specific inhibitors revealed that the proteolytic activity from preimaginal stages is mostly due to trypsin-like serine peptidases that display optimal activity at alkaline $\mathrm{pH}$. In-solution, proteolytic assays of the four larval instars using the fluorogenic substrate Z-Phe-Arg-AMC in the presence or absence of a trypsin-like serine peptidase inhibitor confirmed the results obtained by substrate-SDS-PAGE analysis. The trypsin-like serine peptidases of the four larval instars were functional over a wide range of temperatures, showing activities at $25^{\circ} \mathrm{C}$ and $65^{\circ} \mathrm{C}$, with an optimal activity between $37^{\circ} \mathrm{C}$ and $50^{\circ} \mathrm{C}$.

Conclusion: The combined use of zymography and in-solution assays, as performed in this study, allowed for a more detailed analysis of the repertoire of proteolytic enzymes in preimaginal stages of the insect. Finally, differences in the trypsin-like serine peptidase profile of preimaginal stages were observed, suggesting that such enzymes exert specific functions during the different stages of the life cycle of the insect.
\end{abstract}

Keywords: Culex quinquefasciatus, Preimaginal stages, Trypsin-like serine peptidases, Peptidases, Zymography

\footnotetext{
*Correspondence: jbj@ioc.fiocruz.br

'Laboratório de Biologia Molecular e Doenças Endêmicas, Instituto Oswaldo

Cruz, FIOCRUZ, Rio de Janeiro, RJ, Brazil

${ }^{4}$ Departamento de Engenharia de Biossistemas, Universidade Federal de São

João del Rei, São João del Rei, MG, Brazil

Full list of author information is available at the end of the article
} 


\section{Background}

Culex quinquefasciatus is a widespread insect in tropical and sub-tropical regions of the world that is adapted to the urban environment. In addition to disturbing sleep and causing local allergic reactions when bitten, this mosquito represents an important risk to human and veterinary health because it is involved in the transmission of diverse pathogens, including multiple arboviruses, filarial worms and protozoan parasites [1-10]. Due to the absence of effective vaccines against these pathogens, combating the insect vectors has been the only way to control the spread of these diseases [11].

Peptidases are hydrolytic enzymes that cleave peptide bonds in protein chains. Enzymes from the trypsin-like serine peptidase family are ubiquitous in the animal kingdom and are characterized by a catalytic triad composed of serine, histidine and aspartic acid residues [1214]. In insects, the cleavage of specific proteins by serine peptidases has pivotal roles in oogenesis, immunity, metamorphosis, modulation of embryonic development and nutrition [15-19]. In addition, it has been shown that the expansion of trypsin-like serine peptidase genes in mosquitoes coincides with the development of the hematophagous trait [20]. In fact, serine peptidases are most abundant in the gut of the mosquitoes, where they provide a continuous supply of essential amino acids and energy, from food, for development [17,21]. Furthermore, trypsin-like enzymes secreted in the gut lumen have been implicated in the process of pathogen establishment in several vector insects [22-24].

Given that trypsin-like serine peptidases play essential roles in several physiological processes of mosquitoes, they have been highlighted as potential targets for insect control. The biochemical characterization of these enzymes may provide important clues for the development of new control strategies by either using peptidases as targets or interfering in the production of these enzymes [25-29].

Despite the worldwide impact of $C x$. quinquefasciatus on public health, little is known about the expression of active peptidases in the immature stages of this species [30]. In this study, we have used zymographic assays to characterize the proteolytic profile from the egg, larval and pupal stages of $C x$. quinquefasciatus. We demonstrated that eggs, larvae and pupae express a complex profile of peptidases with high activity in alkaline $\mathrm{pH}$ and sensitivity to trypsin-like serine peptidase inhibitors. In addition, some peptidases were shown to be unique to each developmental stage, whereas other proteolytic enzymes were expressed in all stages.

\section{Methods}

\section{Chemicals}

All chemicals were purchased from Sigma Chem. Co. (USA), unless otherwise specified. Stock solutions of 1,10- phenanthroline $(200 \mathrm{mM})$ and pepstatin $\mathrm{A}(1 \mathrm{mg} / \mathrm{ml})$ were prepared in ethanol, whereas trans-epoxysuccinyl Lleucylamido-(4-guanidino)butane (E-64, $10 \mathrm{mM}$ ) was prepared in water. Phenylmethylsulfonylfluoride (PMSF, $250 \mathrm{mM}$ ) was diluted in isopropanol, and $\mathrm{N} \alpha$-tosyl-L-lysine chloromethyl ketone hydrochloride (TLCK, $100 \mathrm{mM}$ ) and $\mathrm{N}$-p-tosyl-L-phenylalanine chloromethyl ketone (TPCK, $100 \mathrm{mM}$ ) were dissolved in methanol. Peptidase inhibitors were maintained at $-20^{\circ} \mathrm{C}$.

\section{Biological materials}

Eggs, larvae (L1, L2, L3 and L4) and pupae of $C x$. quinquefasciatus were obtained from a closed colony derived from insects captured in the Brazilian state of Rio de Janeiro and maintained in the Laboratório de Fisiologia e Controle de Artrópodes Vetores of the Instituto Oswaldo Cruz (Rio de Janeiro). The eggs were collected 2 days after oviposition and immediately lysed. The larvae were kept at $28^{\circ} \mathrm{C}$ with a photoperiod of 12:12 h (LD).

\section{Zymographic assays}

Eggs, larvae and pupae were washed twice with phosphatebuffered saline (PBS, pH 7.2) and mechanically disrupted in lysis buffer containing $10 \%$ glycerol, $0.6 \%$ Triton X-100, $100 \mathrm{mM}$ Tris- $\mathrm{HCl}(\mathrm{pH} 6.8)$ and $150 \mathrm{mM} \mathrm{NaCl}$ [31]. The resulting extracts were centrifuged at $14000 \times g$ for $30 \mathrm{~min}$ at $4^{\circ} \mathrm{C}$ to remove insoluble material and protein concentration was determined using the Pierce Protein assay, following the manufacturers protocol. Afterwards, samples were resolved as previously described [32]. Briefly, $10 \mu \mathrm{g}$ of protein from each sample was mixed with SDS-PAGE sample buffer (125 mM Tris (pH 6.8), 4\% SDS, 20\% glycerol, $0.002 \%$ bromophenol blue) and loaded in $12 \%$ or $10 \%$ polyacrylamide gels co-polymerized with $0.1 \%$ porcine gelatin for separation at $4^{\circ} \mathrm{C}$ with a constant voltage of $110 \mathrm{~V}$. Peptidase activity was detected as previously reported [33] with few modifications. The gels were incubated in the reaction buffer containing $100 \mathrm{mM}$ sodium acetate (at $\mathrm{pH} 3.5$ or $5.5)$ or $100 \mathrm{mM}$ Tris $-\mathrm{HCl}(\mathrm{pH} 7.5$ or 10.0$)$ at $37^{\circ} \mathrm{C}$ for 0.5 , 1, 2 or $4 \mathrm{~h}$ for larvae; $0.5,1,2,4,6,12$ or $24 \mathrm{~h}$ for pupa; and $6,12,24$ or 48 hours for egg homogenates. Bands of gelatin degradation were visualized by staining the gels with $0.2 \%$ Coomassie blue R-250 in methanol/acetic acid (40:10) and destaining in $10 \%$ acetic acid. The molecular masses of peptidases were estimated by comparison with the mobility of a commercial molecular mass standard (PageRuler ${ }^{\text {rm }}$ Protein Ladder, Fermentas). All results are derived from three independent experiments carried out in triplicate.

\section{Effect of temperature on proteolytic activity}

Gels containing larval homogenates were incubated at $10,25,37,50,65$ or $85^{\circ} \mathrm{C}$ for $2 \mathrm{~h}$ in preheated $100 \mathrm{mM}$ 
Tris- $\mathrm{HCl}$ (pH 7.5), and peptidase activity was determined as described above.

\section{Peptidase inhibition assays}

Egg, larvae and pupa homogenates were pre-incubated for $30 \mathrm{~min}$ at $37^{\circ} \mathrm{C}$ with one of the following peptidase inhibitors: $10 \mu \mathrm{M}$ E-64, $1 \mathrm{mM}$ PMSF, $100 \mu \mathrm{M}$ TLCK, $100 \mu \mathrm{M}$ TPCK, $10 \mu \mathrm{M}$ pepstatin-A or $10 \mathrm{mM}$ 1,10-phenanthroline. After electrophoresis, inhibitors at the same concentration were also added to the reaction buffer, and peptidases were resolved as described above.

\section{In-solution enzymatic assays}

The in-solution determination of peptidase activity from larval homogenates was performed using the fluorogenic substrate Z-carbobenzoxy-L-phenylalanyl-L-arginine-(7amino-4-methylcoumarin) [Z-Phe-Arg-AMC]. The substrate was prepared at a concentration of $3 \mathrm{mM}$ stock in dimethylsulfoxide (DMSO), from which it was diluted to a $100 \mu \mathrm{M}$ working solution for each assay. The reactions proceeded by adding $10 \mu \mathrm{g}$ of proteins from larvae of each instar diluted in $100 \mathrm{mM}$ sodium phosphate buffer ( $\mathrm{pH}$ 7.5). The fluorescence intensity was measured continuously by spectrophotofluorometry (SpectraMax Gemini XPS, Molecular Devices, CA) using excitation and emission wavelengths of 380 and $460 \mathrm{~nm}$, respectively. All assays were performed at $37^{\circ} \mathrm{C}$ and $\mathrm{pH}$ 7.5.
Controls without enzyme or without substrate were also included. All results are derived from three independent experiments carried out in triplicate.

\section{Results}

\section{Peptidase profile and time course of proteolytic activity} from eggs

The zymographic profiling from eggs was evaluated between 6 and $48 \mathrm{~h}$ of incubation at $\mathrm{pH}$ 7.5. The intensity of proteolytic activity increased progressively from 6 to $48 \mathrm{~h}$. However, the complete peptidase profile was better resolved at $24 \mathrm{~h}$ because many bands of activity were overlapping at $48 \mathrm{~h}$. Therefore, the $24 \mathrm{~h}$ time point was used for all subsequent egg enzymatic assays. Eggs presented a peptidase profile composed of eleven bands ranging from 17 to $200 \mathrm{kDa}$, approximately (Figure 1A).

\section{Influence of $\mathrm{pH}$ on the proteolytic activity from eggs}

To analyze the $\mathrm{pH}$ dependence of peptidase activity, the gels were incubated for $24 \mathrm{~h}$ in different buffers ranging from $\mathrm{pH} 3.5$ to 10.0. Enzymatic activity was detected at all assayed $\mathrm{pH}$ levels. Nevertheless, the intensity of the proteolytic profile at $\mathrm{pH} 3.5$ and 5.5 was drastically reduced when compared with those obtained at $\mathrm{pH} 7.5$ and 10.0 (Figure 1B).

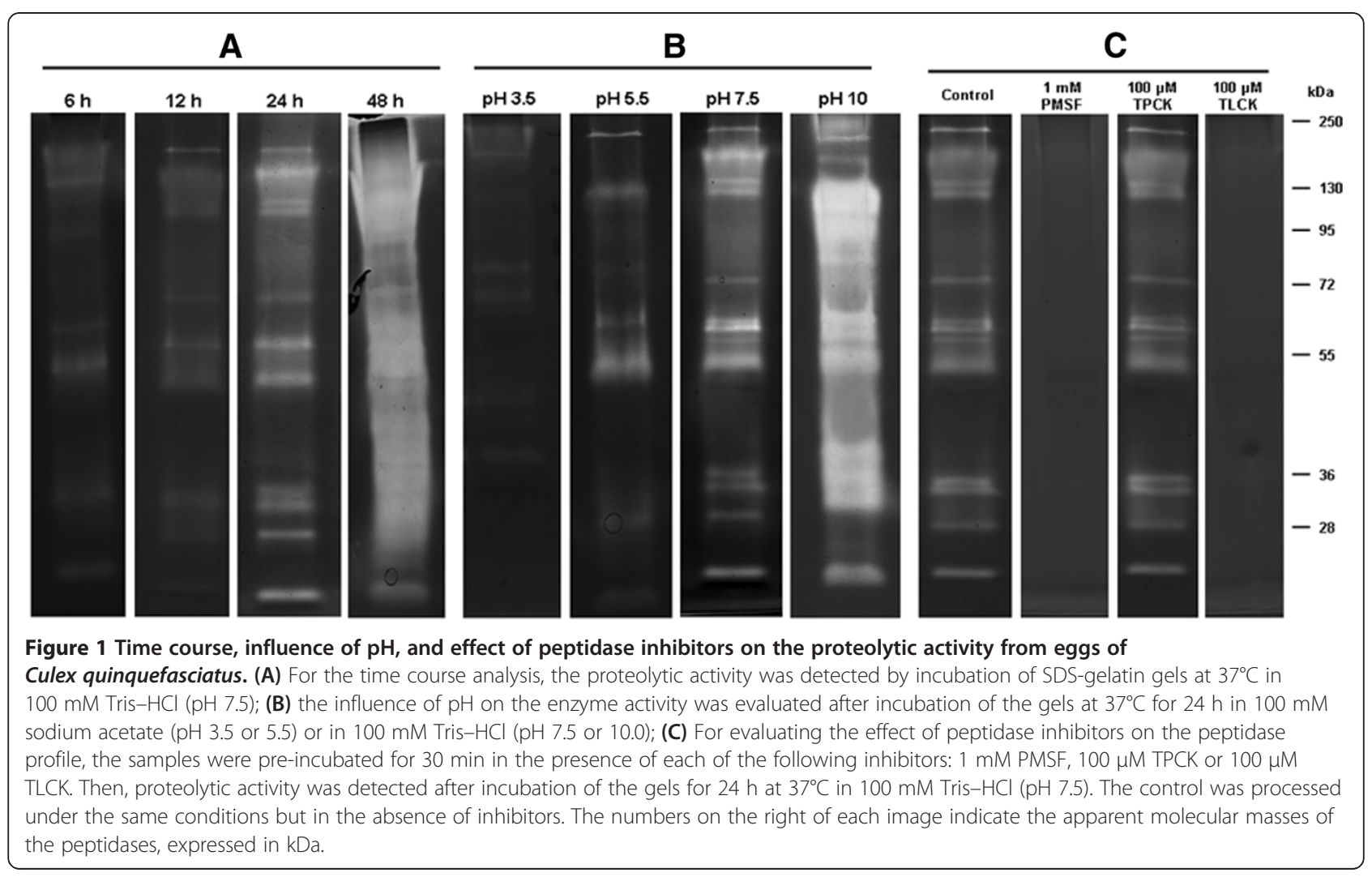




\section{Enzymatic inhibition assays in egg homogenates}

The effect of a number of peptidase inhibitors on proteolytic activity from egg homogenates was determined. TLCK and PMSF strongly inhibited the enzymatic activity whereas TPCK displayed a peptidase profile similar to control (Figure 1C). E-64, pepstatin $\mathrm{A}$, and 1,10-phenanthroline did not affect the enzymatic pattern detected for the egg extracts (data not shown).

\section{Zymographic profiles and time course of proteolytic activity from larval instars}

The zymographic profiles from L1, L2, L3 and L4 larval instars and pupae were analyzed at $0.5,1,2$ and $4 \mathrm{~h}$ buffered at $\mathrm{pH}$ 7.5. The larval peptidase profile was composed of ten or eleven bands ranging from 11 to $130 \mathrm{kDa}$, approximately. Eight bands of intense activity were detected ranging from 28 to $130 \mathrm{kDa}$ and two bands with low activity were observed at $11 \mathrm{kDa}$ (Figure 2). Although larval enzymatic activity was detected at all experimental conditions ( $30 \mathrm{~min}$ to $4 \mathrm{~h}$ ), gels allowed to react for $2 \mathrm{~h}$ clearly resolved the peptidase composition of all larval instars. Therefore, this time point was used routinely for all subsequent larval enzymatic assays. The experimental conditions used here were adequate for the detection of peptidase activity in all larval instars but did not allow the detection of proteolytic activity in pupae.

\section{Influence of $\mathrm{pH}$ on the proteolytic activity from} larval instars

Enzymatic activity from all larval instars was detected at each $\mathrm{pH}$ level tested (Figure 3). Nevertheless, the intensity of the proteolytic profile at $\mathrm{pH} 7.5$ and 10.0 was higher than that observed at $\mathrm{pH} 3.5$ and 5.5. At $\mathrm{pH} 10.0$, some of the proteolytic halos overlapped, precluding the distinction of each band. The experimental conditions used here were adequate for the detection of peptidase activity in all larval instars but were not ideal for detecting proteolytic activity in pupae, suggesting that reaction times and $\mathrm{pH}$ conditions had to be determined separately for pupal analysis.

\section{Enzymatic inhibition assays in larval instar homogenates} The enzymatic pattern present in the larval homogenates was strongly inhibited by TLCK and PMSF,

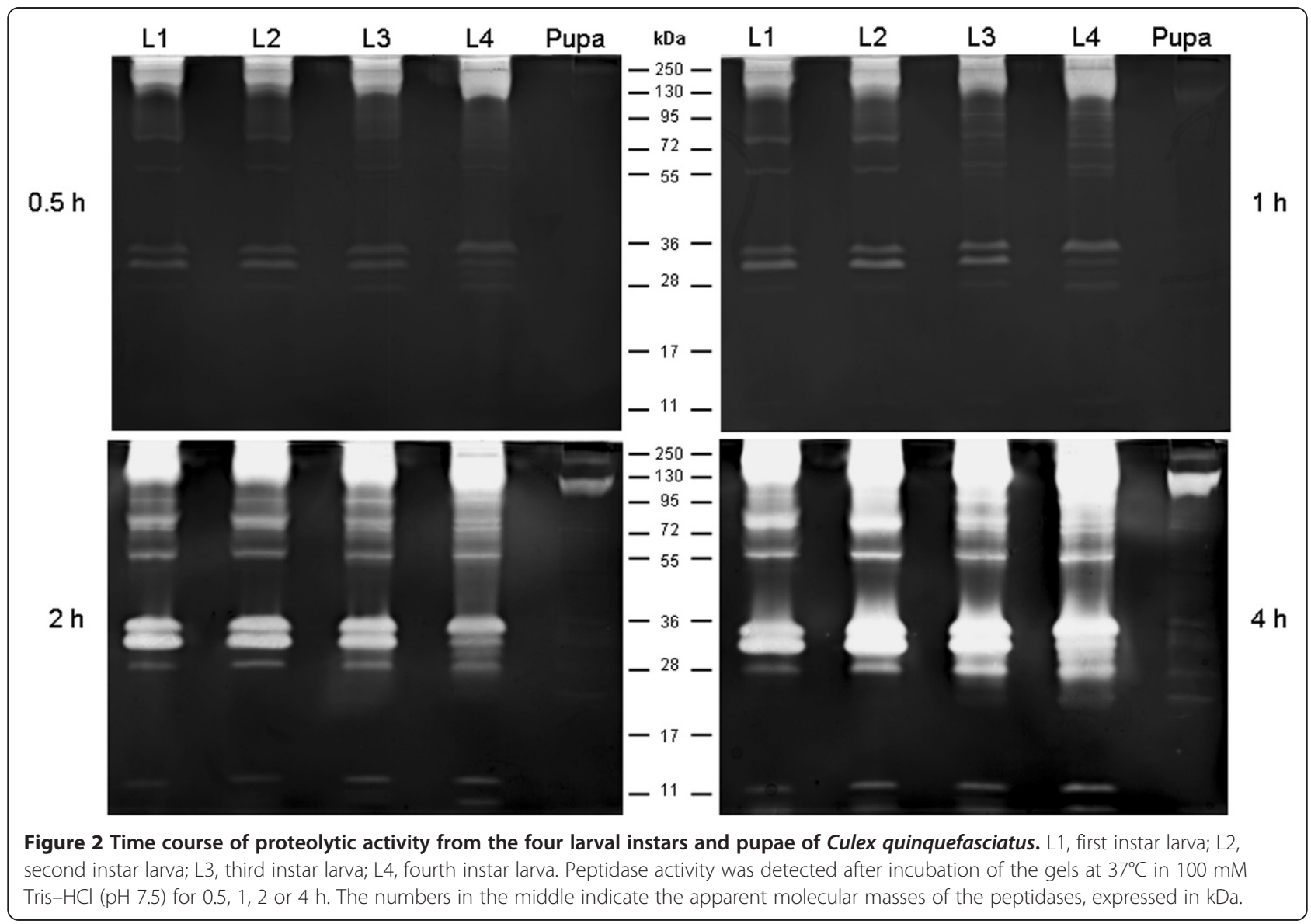




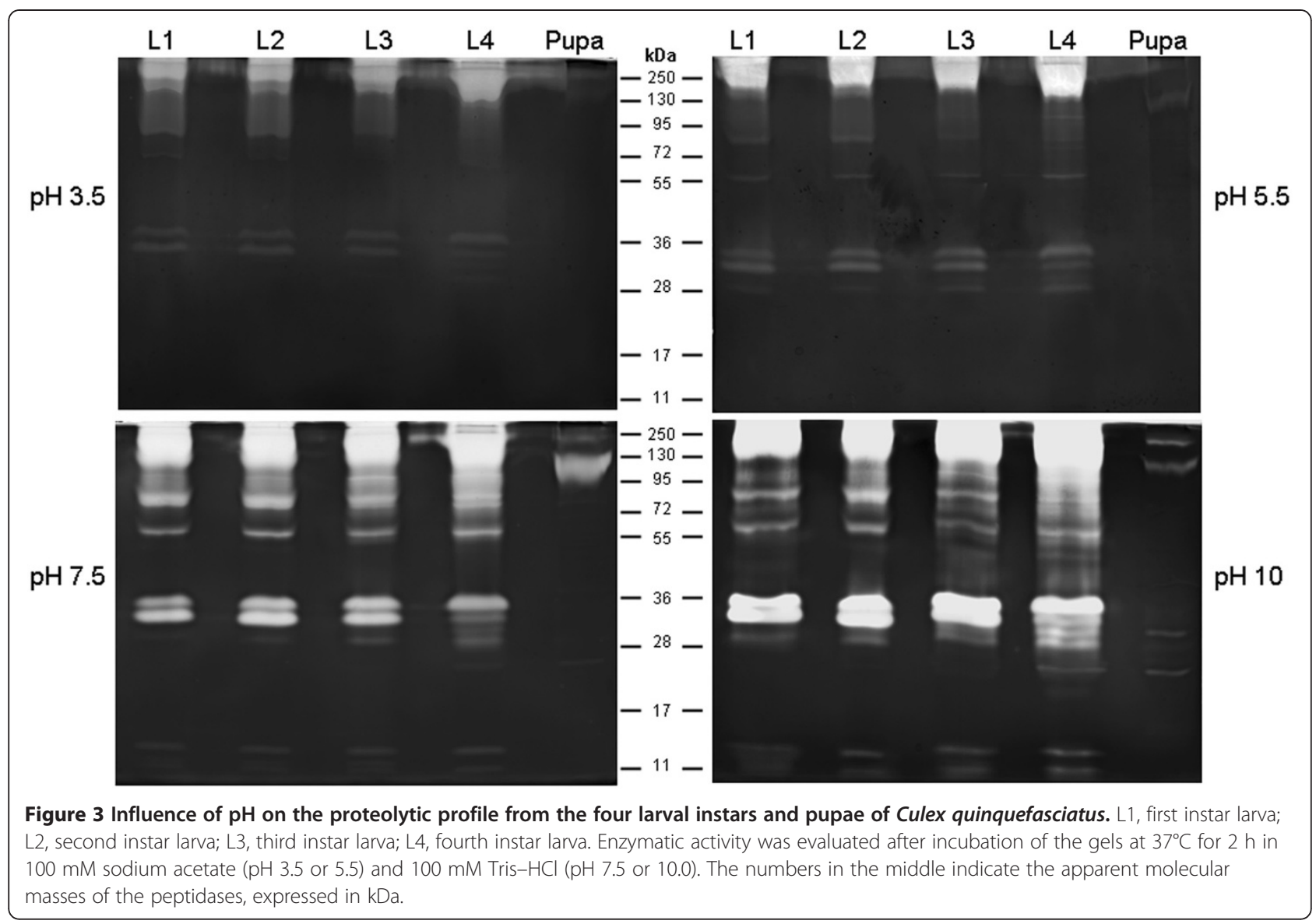

whereas TPCK displayed a peptidase profile similar to the control (Figure 4). E-64, pepstatin A, and 1,10-phenanthroline did not affect the enzymatic pattern detected for all larval instars (data not shown).

\section{Effect of temperature on peptidase activity in larval instar homogenates}

Low peptidase activity was observed for all larval instars when samples were incubated at temperatures ranging from 10 to $25^{\circ} \mathrm{C}$. Optimal peptidase activity was observed

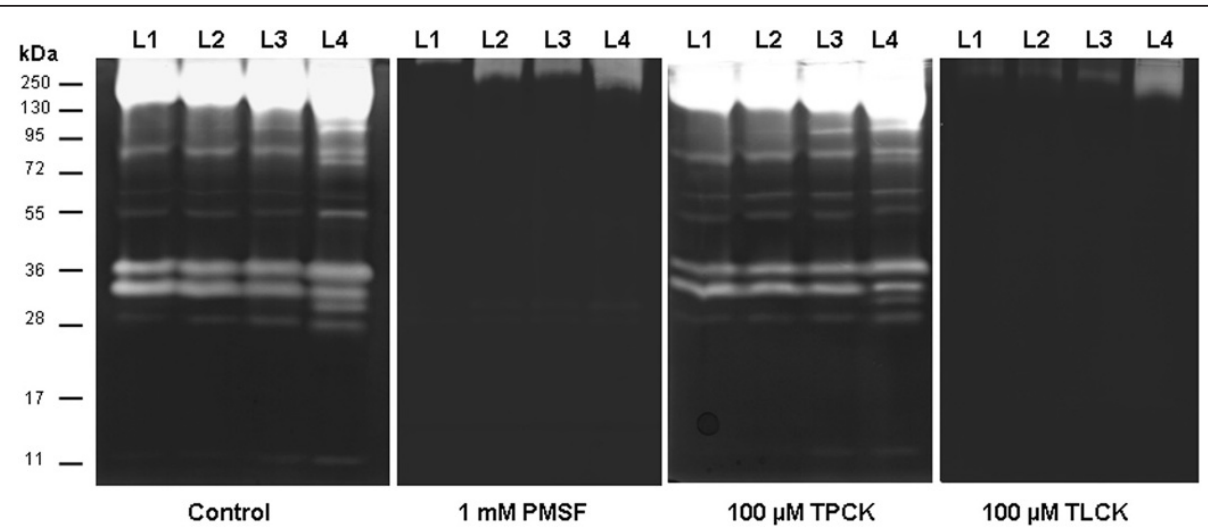

Figure 4 Effect of peptidase inhibitors on the proteolytic profile from larval instars of Culex quinquefasciatus. The samples were preincubated for $30 \mathrm{~min}$ in the presence of each of the following inhibitors: $1 \mathrm{mM}$ PMSF, $100 \mu \mathrm{M}$ TPCK or $100 \mu \mathrm{M}$ TLCK. Then, the proteolytic activity was detected after incubation of the gels for $2 \mathrm{~h}$ at $37^{\circ} \mathrm{C}$ in $100 \mathrm{mM}$ Tris- $\mathrm{HCl}(\mathrm{pH}$ 7.5). The control was processed under the same conditions but in the absence of inhibitors. The numbers on the right indicate the apparent molecular masses of the peptidases, expressed in $\mathrm{kDa}$. 


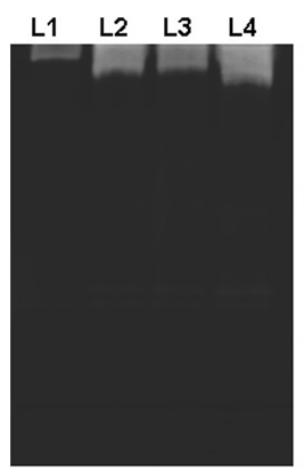

$10^{\circ} \mathrm{C}$

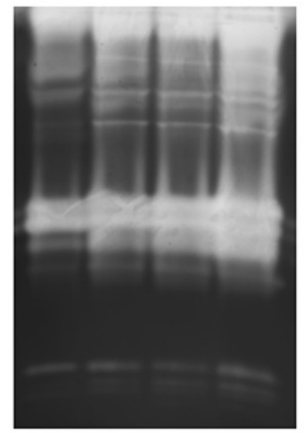

$50^{\circ} \mathrm{C}$

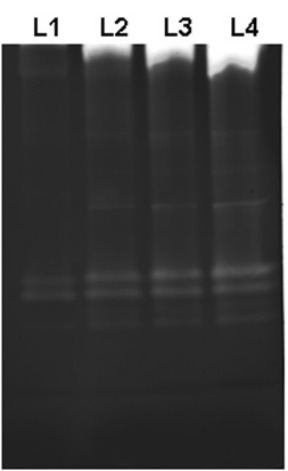

$25^{\circ} \mathrm{C}$

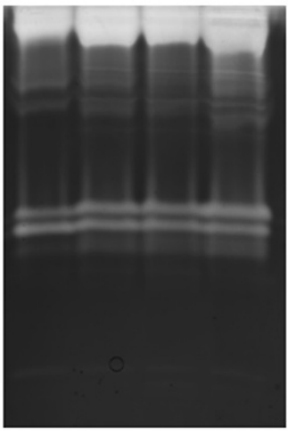

$65^{\circ} \mathrm{C}$

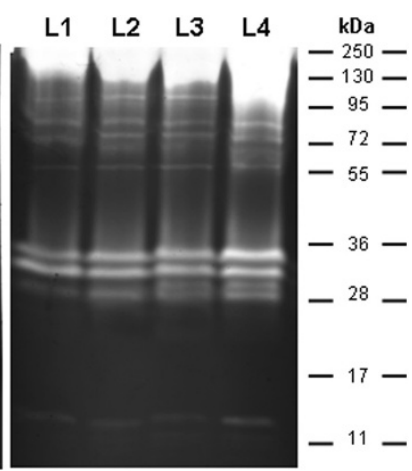

$37^{\circ} \mathrm{C}$

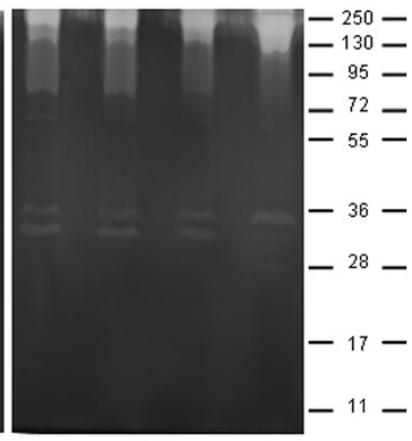

$85^{\circ} \mathrm{C}$

Figure 5 Effect of temperature on proteolytic activity from larval instars of Culex quinquefasciatus. Enzyme activity was detected after incubation of the gels for $2 \mathrm{~h}$ at 10,25,37, 50, 65 or $85^{\circ} \mathrm{C}$ in $100 \mathrm{mM}$ Tris- $\mathrm{HCl}(\mathrm{pH} 7.5)$. The numbers on the right indicate approximate molecular masses of the peptidases, expressed in $\mathrm{kDa}$.

at $37^{\circ} \mathrm{C}$, with a strong increase when samples were incubated at $50^{\circ} \mathrm{C}$. This activity was reduced at 65 and $85^{\circ} \mathrm{C}$ (Figure 5).

\section{Zymographic profiles and time course of proteolytic activity from the pupal stage}

The enzymatic profile from the pupal stage was evaluated using reaction times of $0.5,1,2,4,6,12$ and $24 \mathrm{~h}$ in $100 \mathrm{mM}$ Tris- $\mathrm{HCl}$ (pH 7.5). No activity was observed at $0.5,1$ and $2 \mathrm{~h}$, but proteolysis increased progressively from 4 to $24 \mathrm{~h}$ (Figures 2 and 6). The enzymatic profile was best resolved at $12 \mathrm{~h}$, allowing the visualization of 15 degradation halos, ranging from approximately 17 to $130 \mathrm{kDa}$.

\section{Effect of $\mathrm{pH}$ on the proteolytic profile of the pupal stage} Peptidase activity from pupae was detected at $\mathrm{pH}$ levels from 5.5 to 10.0 , whereas no proteolytic band was detected at $\mathrm{pH} 3.5$ (Figure 7). Because the bands exhibiting proteolytic activity overlapped at $\mathrm{pH} 10.0$, the $\mathrm{pH} 7.5$ was chosen for the subsequent characterization of pupal peptidases.

\section{Effect of inhibitors on the proteolytic activity of the pupal} stage

The enzymatic profile exhibited by pupal homogenates was strongly inhibited by TLCK and PMSF but not by TPCK
(Figure 8). E-64, pepstatin A or 1,10-phenanthroline showed no effect on the peptidase activity of pupae (data not shown).

\section{In-solution detection of proteolytic activity}

Proteolytic activity from larval instars was determined using the fluorogenic substrate Z-Phe-Arg-AMC in the presence or absence of TLCK, a specific inhibitor of trypsin-like serine peptidases. All larval instar extracts were able to degrade the substrate. Proteolytic activities increased progressively from L1 to L4 with each instar displaying distinct velocities of substrate degradation. All enzymatic activities were strongly inhibited by TLCK (Figure 9).

\section{Discussion}

This study presents zymographic characterization and comparative analysis of proteolytic activity in eggs, larval instars and pupae of $C x$. quinquefasciatus. The timecourse assays demonstrated that the most complete profile of active peptidases were obtained at an incubation time of $24 \mathrm{~h}$ for eggs, $2 \mathrm{~h}$ for larvae and $12 \mathrm{~h}$ for pupae. The proteolytic activity was evaluated both for sensitivity to inhibitors and $\mathrm{pH}$ dependence. The use of PMSF, an inhibitor specific for serine peptidases, revealed that serine peptidases are responsible for the proteolytic 


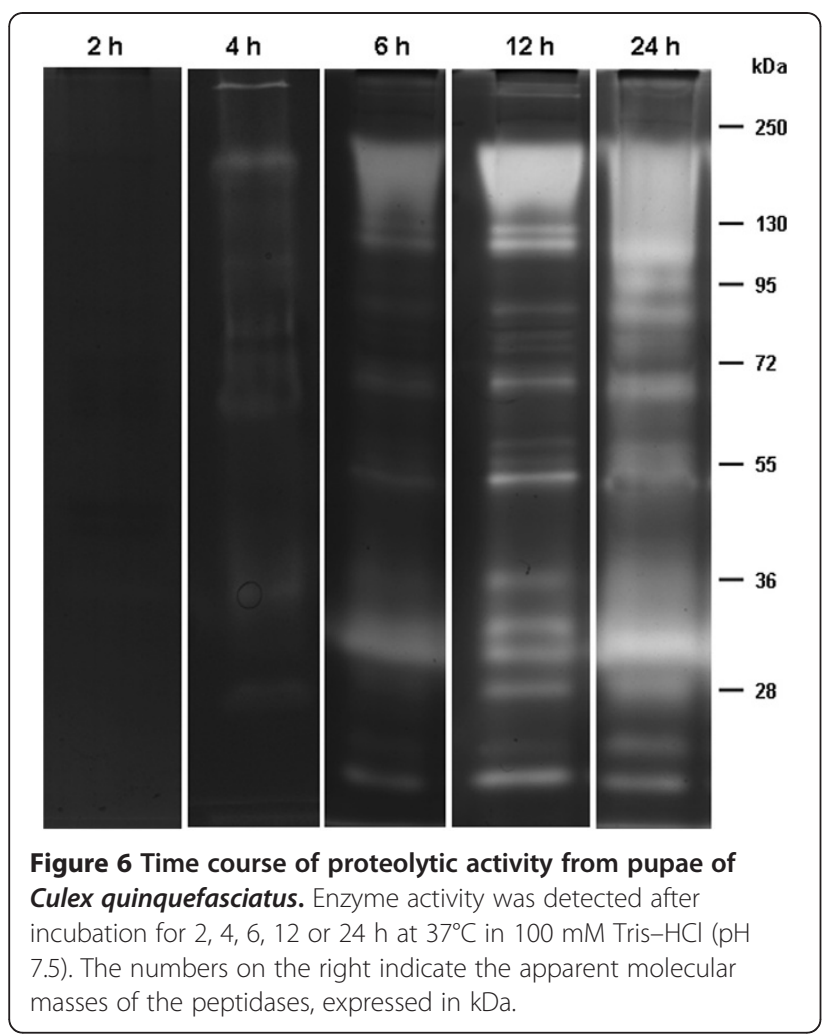

activity detected for all stages. To determine whether such enzymes were trypsin- or chymotrypsin-like serine peptidases, other class-specific inhibitors were used. All activity bands were strongly inhibited by TLCK, a trypsin inhibitor, indicating that the serine peptidases detected here belong to the trypsin-like family. In addition, in-solution assays performed using the synthetic fluorogenic substrate Z-Phe-Arg-AMC confirmed the results obtained in zymographic analysis using substrate-SDS-PAGE. Serine peptidases form one of the largest families of peptidases in mosquitoes, occurring in different tissues and stages of development [17,34-36]. Trypsin-like and chymotrypsin-like serine enzymes are the dominant digestive peptidases in many larvae and adult insects. Our analyses revealed a much more complex profile of trypsin-like activity in all preimaginal stages of $C x$. quinquefasciatus when compared with zymographic analyses of other Diptera such as Ceratitis capitat and Lutzomyia longipalpis, as well as of other insect orders like Lepidoptera (Achaea janat and Heliothis virescens) and some Coleoptera (Chrysomya bezziana, Cynaeus angustus, Morimus funereus, Tenebrio molitor and Tribolium castaneum) [24,37-42]. In fact, it has been demonstrated that the trypsin-like serine peptidase family has evolved both in size and in complexity among the mosquitoes. It has been suggested that trypsin-like serine peptidase genes have undergone an expansion in mosquitoes most likely driven by the acquisition of the hematophagous trait. However, the size variation of this gene family is small among mosquito species [20]. Wide proteomic and genomic analyses of An. gambiae and Drosophila melanogaster identified 305 and 206 functional trypsin-like genes, respectively [43], whereas, $C x$. quinquefasciatus and Aedes aegypti genomes were shown to contain 403 and 380 trypsin-like serine peptidase genes, respectively [20]. These data indicate that $A e$. aegypti and $C x$. quinquefasciatus genomes code for $\sim 46 \%$ and $\sim 55 \%$ more trypsin-like serine peptidases than D. melanogaster [43]. Therefore, the complexity of active serine peptidase expression in preimaginal forms of $C x$. quinquefasciatus may reflect the expansion of these genes in this mosquito. Previous reports from our group have shown that preimaginal stages of Ae. aegypti also exhibit a complex profile of trypsin-like serine peptidases [33], similar to those observed here for $C x$. quinquefasciatus.

Like most insect serine peptidases, the $C x$. quinquefasciatus trypsin-like serine peptidases were active over a broad $\mathrm{pH}$ range (5.5 to 10.0). Indeed, all activity was strongly detected at $\mathrm{pH} 10.0$ in eggs, larvae and pupae, but the hyperactivity of

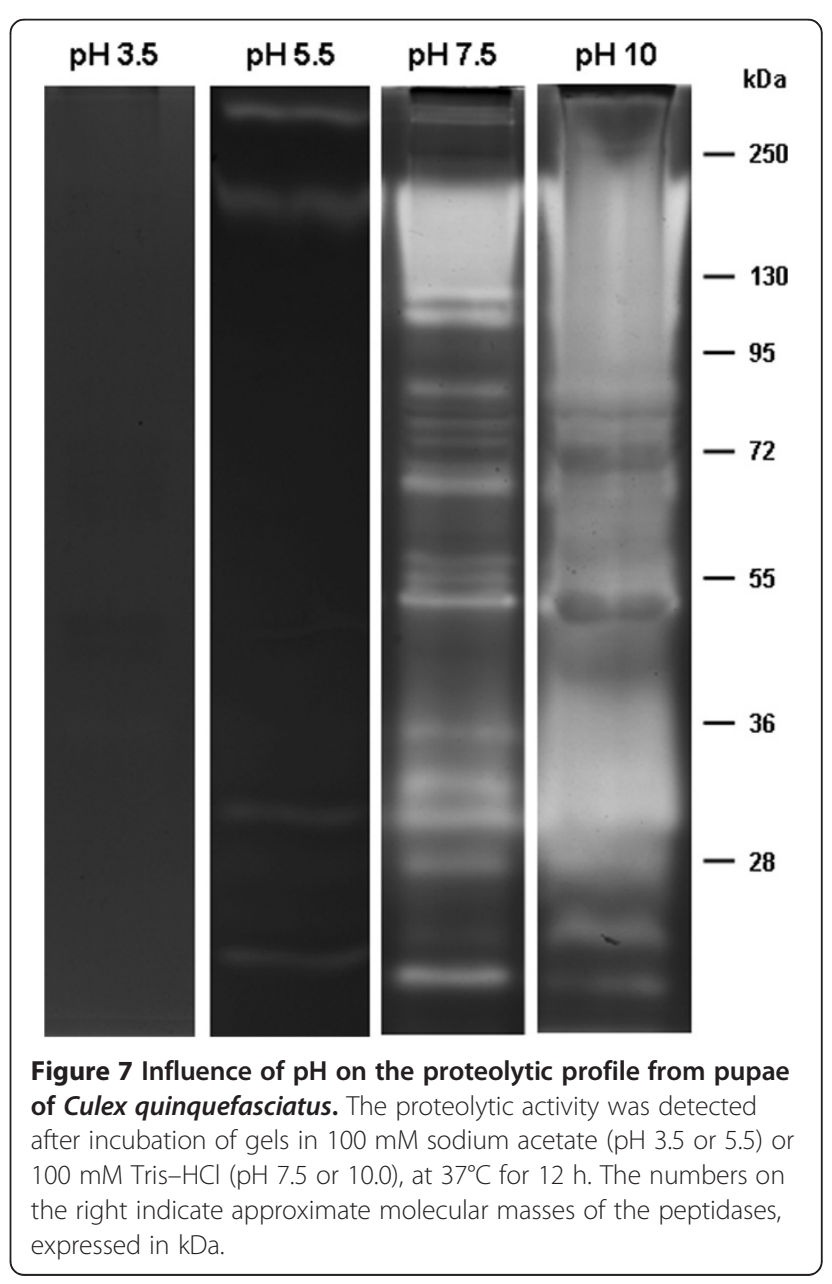




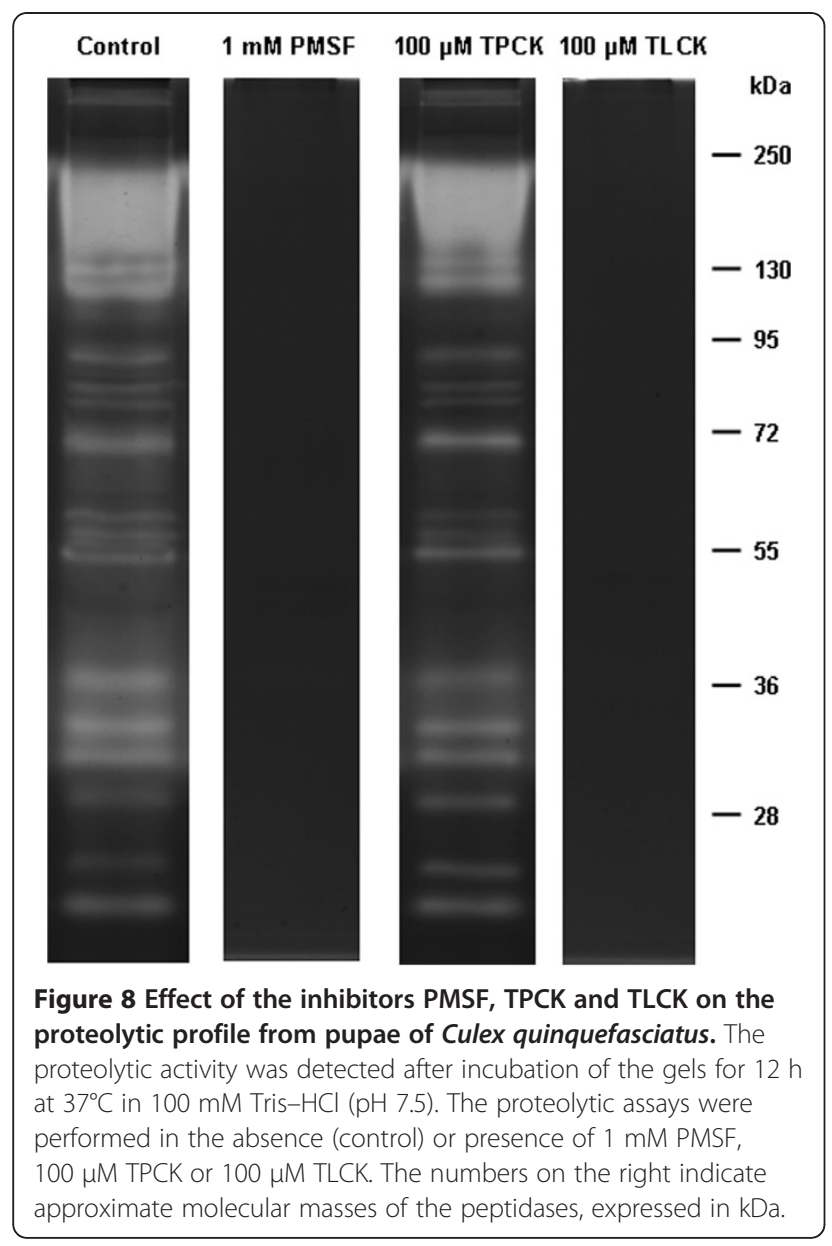

peptidases at this $\mathrm{pH}$ produced overlapping zones and smears in some regions of the gel, causing activity bands to blur and compromising comparative analysis. To avoid this, an optimal pH level of 7.5 allowed for the detection of the complete serine peptidase profile for all analyzed stages. Similarly, larvae of other Diptera such as Oxysarcodexia thornax, Ae. aegypti and Lu. longipalpis were shown to exhibit serine peptidase activity over a wide range of alkaline $\mathrm{pH}[32,33,44]$.

Our results showed that the serine peptidase profile of preimaginal stages of $C x$. quinquefasciatus is stagespecific, displaying qualitative and quantitative differences in activity detected by zymography. Some trypsinlike serine peptidase activities were found for all stages, suggesting that these enzymes are constitutively expressed during developmental stages and that they exert common functions in all analyzed stages. Comparison of the proteolytic profile of eggs and larvae showed that they share bands migrating between 28 to $36 \mathrm{kDa}$ and 55 to $72 \mathrm{kDa}$, whereas they differ by a band at $17 \mathrm{kDa}$ that is present in the egg but absent in the larvae, and also by two bands at $11 \mathrm{kDa}$ that are present in the larvae but absent in the eggs. The activity detected for eggs may be supported by the necessity of yolk protein digestion or tissue remodeling during embryological development. In this phase, the hydrolysis of yolk proteins is required to release amino acids and peptides steadily during the first $16 \mathrm{~h}$ of preembryonic development $[30,45]$. Serine carboxypeptidases are synthesized in the fat body of Ae. aegypti, transported through the hemolymph, and taken up by oocytes [46]. This protease is synthesized as a zymogen and activated within eggs during embryogenesis. Thus, the proteolytic profile detected for the egg homogenates may be composed of activities present in both the preembryonic stage and the fully developed larval embryos. In fact, the eggs that were used were two days post oviposition; thus, in this condition, the embryological development had ended, and the embryo was structurally similar to a young L1 instar. Peptidases with specific roles in embryogenesis and hatching have been described in other insects such as Bombyx mori [47], Rhodnius prolixus [48] and Lucilia cuprina [49,50].

The complex proteolytic profile exhibited by the pupal stage also revealed qualitative differences between the profiles of eggs and larvae. It was observed that this stage exhibits one band at approximately $36 \mathrm{kDa}$ that is not present in the other preimaginal stages. We also observed that the pupa displays two bands at approximately $17 \mathrm{kDa}$, whereas the egg displays only one band in this region. In addition, quantitative differences in the expression of trypsin-like serine peptidase activities were observed during the time-course assays (24 h for eggs, $2 \mathrm{~h}$ for larvae and $12 \mathrm{~h}$ for pupae). Such differences could be related to the expression of peptidases specifically involved in larval nutrition because the larval instars feed actively whereas pupae and eggs do not. $C x$. quinquefasciatus larvae can live in water containers with high levels of pollution and microbial fauna, where they feed by filtering various material from the environment. The occurrence of highly active trypsin-like enzymes in larvae when compared with eggs and pupae may be related to the digestion of this complex diet. A large trypsin-like serine peptidase repertoire may help larvae to respond to changes in diet composition or biological inhibitors [17]. This activity then drops after larval-pupa ecdysis and remains at a low level beyond the pupaladult ecdysis [51]. Trypsin in pupae could be related to proteolysis of the remaining larval tissue during metamorphosis [17]. The differences observed in the proteolytic profiles among the preimaginal stages indicate that the expression of active peptidases is finely regulated. However, the mechanisms involved in such regulation are not yet well understood. The reduction and/or suppression of the expression of peptidases, such as those involved in larval feeding, and the increase and/or induction of the expression of peptidases that have 


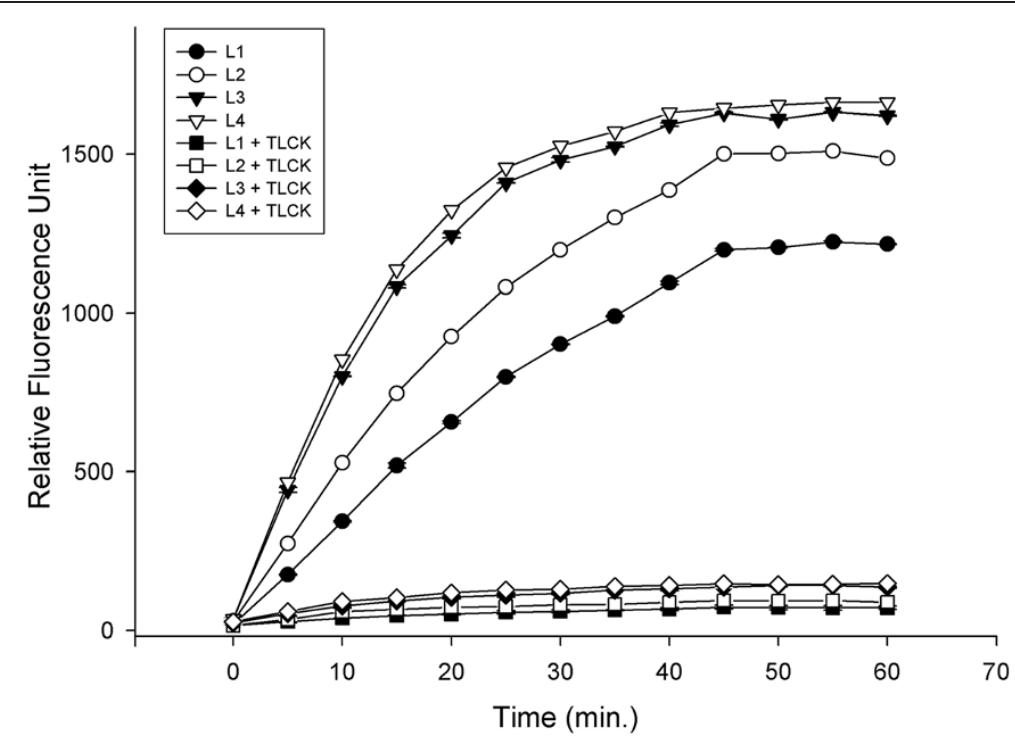

Figure 9 Detection of proteolytic activity from the four larval instars of Culex quinquefasciatus using the fluorogenic substrate Z-Phe-Arg-AMC. The proteolytic assays were performed in the absence (control) or presence of $100 \mu \mathrm{M}$ TLCK in $100 \mathrm{mM}$ sodium phosphate (pH 7.5).

functions in the eggs or pupa themselves, should be under the control of some type of regulation during the life cycle.

It was also observed here that peptidase expression in larvae increases at each larval stage. The quantitative differences in proteolytic activity could be related to the differential expression of these enzymes in the distinct larval instars; this phenomenon has also been observed in other species of Culicidae, specifically in the gut, using methodologies other than zymography $[28,52]$. The experiments performed with the fluorogenic substrate Z-Phe-Arg -AMC also confirmed this observation. In addition, the zymographic analysis used here facilitated the observation of different bands that appear during larval development, which are not evident by other methods. Comparative analysis of larval instars revealed bands migrating between 25 and $36 \mathrm{kDa}$ at the fourth instar that were not observed in the other larval instars. Therefore, the combined use of zymography and in-solution assays allowed for a more detailed analysis of the repertoire of proteolytic enzymes.

Despite different studies that have reported serine peptidases with high molecular masses [37,39-42], it is expected that monomeric forms of trypsin-like enzymes migrate at 24-35 kDa. Our results, however, showed enzymes with tryptic activity migrating between 55 and $130 \mathrm{kDa}$. Because the protein samples are not completely denatured or reduced, it is unclear whether the higher molecular weight proteins are actual trypsin polypeptides, protein aggregates or even peptidases bound to some amount of membrane that precipitated at the top of the gels. As mentioned by others, such factors may slow the migration of the peptidases [53]. Membrane- bound trypsin occurs in microvilli and other cell membranes of insect gut $[54,55]$. Thus, during lysis of preimaginal insect samples, some peptidases may be released with their membrane anchors, which may influence their migration through the gel but not prevent their activity. In spite of such events, it is important to highlight that zymography in substrate-SDS-PAGE is a highly reproducible methodology if protocols are well standardized.

Experiments on the effect of temperature on proteolytic profiles showed that despite low enzymatic activity at $10^{\circ} \mathrm{C}$ and $25^{\circ} \mathrm{C}$, the proteolytic profile of the four larval instars could still be observed. Enzymatic activity increased from $37^{\circ} \mathrm{C}$ to $50^{\circ} \mathrm{C}$, and then decreased at $65^{\circ} \mathrm{C}$ and $85^{\circ} \mathrm{C}$, indicating that trypsin-like serine peptidases of $C x$. quinquefasciatus larvae support extreme temperature conditions. Nevertheless, incubation above $65^{\circ} \mathrm{C}$ led to a strong decrease of activity most likely due to the thermal denaturation of the enzymes. Similar results were described for serine peptidases of Ae. aegypti [33], O. ovis [56] and T. molitor [57,58].

\section{Conclusion}

To our knowledge, this is the first zymographic study of trypsin-like serine peptidases in preimaginal stages of $C x$. quinquefasciatus. We showed that such stages displayed a complex proteolytic profile with multiple bands, which exhibited optimal activity at alkaline $\mathrm{pH}$ and over a wide range of temperature. In addition, the comparative approach used here allowed us to detect differences in the expression of active peptidases in the analyzed stages and permitted the assignment of specific trypsin activity to each 
stage. The presence of multiple bands of activity of trypsinlike serine peptidases in $C x$. quinquefasciatus may be due to occurrence of multiple coding genes in its genome. Such multiplicity could confer an evolutionary advantage that would allow the insect to cope with a variety of peptidase inhibitors during its life cycle. Understanding of the differential expression of trypsin-like serine peptidase profiles during the $C x$. quinquefasciatus life cycle is important to determine the role of these enzymes during developmental stages of the insect.

\section{Competing interests}

The authors declare that they have no competing interests.

\section{Authors' contributions}

$J B J$ and PC designed the study. ABV, LSV, RCP and NF performed the experimental work. ABV, LSV, PC and JBJ analyzed the data. ABV, PC and JBJ prepared the manuscript with the critical input of CMd'AL and CB. All authors read and approved the final manuscript.

\section{Acknowledgements}

This was supported by FIOCRUZ-IOC, FAPEMIG (APQ-02093-09), CNPq, CAPES and FAPERJ. We thank Prof. Dr. José Bento Pereira Lima and Prof. Dr. Denise Valle (Laboratório de Fisiologia e Controle de Artrópodes Vetores of the Instituto Oswaldo Cruz) for kindly providing the insects.

\section{Author details}

'Laboratório de Biologia Molecular e Doenças Endêmicas, Instituto Oswaldo Cruz, FIOCRUZ, Rio de Janeiro, RJ, Brazil. ${ }^{2}$ Laboratório de Pesquisa em Leishmaniose, Instituto Oswaldo Cruz, FIOCRUZ, Rio de Janeiro, RJ, Brazil. ${ }^{3}$ Laboratório de Biologia de Tripanossomatíl, Instituto Oswaldo Cruz, FIOCRUZ, Rio de Janeiro, RJ, Brazil. ${ }^{4}$ Departamento de Engenharia de Biossistemas, Universidade Federal de São João del Rei, São João del Rei, MG, Brazil.

Received: 17 April 2012 Accepted: 12 June 2012

Published: 20 June 2012

\section{References}

1. Arensburger P, Megy K, Waterhouse RM, Abrudan J, Amedeo P, Antelo B, Bartholomay L, Bidwell S, Caler E, Camara F, Campbell CL, Campbell KS, Casola C, Castro M, Chandramouliswaran I, Chapman SB, Christley S, Costas J, Eisenstadt E, Feschotte C, Fraser-Liggett C, Guigo R, Haas B, Hammond M, Hansson BS, Hemingway J, Hill SR, Howarth C, Ignell R, Kennedy RC, Kodira CD, Lobo NF, Mao C, Mayhew G, Michel K, Mori A, Liu N, Naveira H, Nene V, Nguyen N, Pearson MD, Pritham EJ, Puiu D, Qi Y, Ranson H, Ribeiro JMC, Roberston HM, Severson DW, Shumway M, Stanke M, Strausberg RL, Sun Cheng, Sutton G, Tu ZJ, Tubio JMC, Unger MF, Vanlandingham DL, Vilella AJ, White O, White JR, Wondji CS, Wortman J, Zdobnov EM, Birren B, Christensen BM, Collins FH, Cornel A, Dimopoulus G, Hannick LI, Higgs S, Lanzaro GC, Lawson D, Lee NH, Muskavitch MAT, Raikhel AS, Atkinson PW: Sequencing of Culex quinquefasciatus establishes a platform for mosquito comparative genomics. Science 2010, 330:86-88.

2. Bartholomay LC, Waterhouse RM, Mayhew GF, Campbell CL, Michel K, Zou Z, Ramirez JL, Das S, Alvarez K, Arensburger P, Bryant B, Chapman SB, Dong Y, Erickson SM, Karunaratne SHPP, Kokoza V, Kodira CD, Pignatelli P, Shin SW, Vanlandingham DL, Atkinson PW, Birren B, Christophides GK, Clem RJ, Hemingway J, Higgs S, Megy K, Ranson H, Zdobnov EM, Raikhel AS, Christensen BM, Dimopoulos G, Muskavitch MAT: Pathogenomics of Culex quinquefasciatus and Meta-Analysis of infection responses to diverse pathogens. Science 2010, 330:88-90.

3. Ruiz MO, Chaves LF, Hamer GL, Sun T, Brown WM, Walker ED, Haramis L, Goldberg TL, Kitron UD: Local impact of temperature and precipitation on West Nile virus infection in Culex species mosquitoes in northeast Illinois, USA. Parasit Vectors 2010, 3:19.

4. Bisanzio D, Giacobini M, Bertolotti L, Mosca A, Balbo L, Kitron U, VazquezProkopec GM: Spatio-temporal patterns of distribution of West Nile virus vectors in eastern Piedmont Region, Italy. Parasit Vectors 2011, 4:230.
5. Hubalek Z, Halouzka: West Nile fever: a re-emerging mosquito borne viral disease in Europe. Emerg Infect Dis 1999, 5:643-650.

6. Diaz-Badillo A, Bolling BG, Perez-Ramirez G, Moore CG, Martinez-Munoz JP, Padilla-Viveros AA, Camacho-Nuez M, Diaz-Perez A, Beaty BJ, de Lourdes Munoz M: The distribution of potential West Nile virus vectors, Culex pipiens pipiens and Culex pipiens quinquefasciatus (Diptera: Culicidae), in Mexico City. Parasit Vectors 2011, 4:70.

7. Ahid SM, Vasconcelos OS, Lourenço-de-Oliveira R: Vector competence of Culex quinquefasciatus Say from differents regions of Brazil to Dirofilaria immitis. Mem Inst Oswaldo Cruz 2000, 95:769-775.

8. Lai CH, Tung KC, Ooi HK, Wang JS: Competence of Aedes albopictus and Culex quinquefasciatus as a vector of Dirofilaria immmitis after blood meal with different microfilarial density. Vet Parasitol 2000, 90:231-237.

9. Farid HA, Hammad RE, Hassan MM, Morsy ZS, Kamal IH, Weil GJ, Ramzy RMR: Detection of Wuchereria bancrofti in mosquitoes by the polymerase chain reaction: a potentially useful tool for large-scale control programs. Trans R Soc Trop Med Hyg 2001, 95:29-32.

10. Atkinson CT, Dusek RJ, Woods KL, Iko WM: Pathogenicity of avian malaria in experimentally-infected Hawaii amakihi. J Wildl Dis 2000, 36:197-204.

11. Mackenzie JS, Gubler DJ, Petersen LR: Emerging flaviviruses: the spread and resurgence of Japanese encephalitis, West Nile and dengue viruses. Nat Med 2004, 10:98-109.

12. Polgár L: The catalytic triad of serine peptidases. Cell Mol Life Sci 2005, 62:2161-2172.

13. Puente XS, Sanchez LM, Gutierrez-Fernandez A, Velasco G, Lopez-Otin C: A genomic view of the complexity of mammalian proteolytic systems. Biochem Soc Trans 2005, 33:331-334.

14. Rawlings ND, Barrett AJ: Families of serine peptidases. Meth Enzymol 1994, 244:19-61

15. Borovsky D, Schlein Y: Quantitative determination of trypsin-like and chymotrypsin-like enzymes in insects. Arch Insect Biochem Physiol 1988, 8:249-260.

16. Ohtsuki S, Homma K, Kurata S, Komano H, Natori S: A prolyl Endopeptidase of Sarcophaga peregrina (Flesh Fly): its purification and suggestion for its participation in the differentiation of the imaginal discs. J Biochem 1994, 115:449-453.

17. Terra WR, Ferreira C: Insect digestive enzymes: properties, compartimentalization and function. Comp Biochem Physiol 1994, 47:47-61.

18. Nakajima Y, Tsuji Y, Homma K, Natori S: A novel protease in the pupal yellow body of Sarcophaga peregrina (flesh fly). Its purification and CDNA cloning. J Biol Chem 1997, 272:23805-23810.

19. Gorman MJ, Paskewitz SM: Serine proteases as mediators of mosquito immune responses. Insect Biochem Mol Biol 2001, 31:257-262.

20. Wu DD, Guo-Dong W, Irwin DM, Zhang YP: A profound role for the expansion of trypsin-like serine protease family in the evolution of hematophagy in mosquito. Mol Biol Evol 2009, 26:2333-2341.

21. Noriega FG, Wells MA: A molecular view of trypsin synthesis in the midgut of Aedes aegypti. J Insect Physiol 1999, 45:613-620.

22. Shahabuddin M, Kaslow DC: Biology of the development of Plasmodium in the mosquito midgut: a molecular and cellular view. Bull Inst Pasteur 1994, 92:119-132.

23. Shahabuddin M, Costero A: Spatial distribution of factors that determine sporogonic development of malaria parasites in mosquitoes. Insect Biochem Mol Biol 2001, 31:231-240.

24. Telleria EL, Araújo APOd, Secundino NF, d'Avila-Levy CM, Traub-Csekö YM: Trypsin-Like Serine Proteases in Lutzomyia longipalpis - Expression, Activity and Possible Modulation by Leishmania infantum chagasi. PLOS One 2010, 5:e10697.

25. Broadwell AH, Baumann P: Proteolysis in the gut of mosquito larvae results in further activation of the Bacillus sphaericus toxin. Appl Environ Microbiol 1987, 53:1333-1337.

26. Nicolas L, Lecroisey A, Charles JF: Role of the gut proteinases from mosquito larvae in the machanism of action and the specificity of the Bacillus sphaericus toxin. Can J Microbiol 1990, 36:804-807.

27. Borovsky D, Mahmood F: Feeding the mosquito Aedes aegypti with TMOF and its analogs; effect on trypsin biosynthesis and egg development. Regul Pept 1995, 57:273-281.

28. Borovsky D, Meola SM: Biochemical and cytoimmunological evidence for the control of Aedes aegypti larval trypsin with Aea-TMOF. Arch Insect Biochem Physiol 2004, 55:124-139.

29. Lau YS, Sulaiman S, Othman H: The effectiveness of Trypsin Modulating Oostatic Factor (TMOF) and combinations of TMOF with Bacillus 
thuringiensis against Aedes aegypti larvae in the laboratory. Iran J Arthropod-Borne Dis 2011, 5:13-19.

30. Clements AN: The Biology of mosquitoes, Development, Nutrition and Reproduction, Volume 1. London: Chapman \& Hall; 1992.

31. Galán JE, Pace J, Hayman MJ: Involvement of the epidermal growth factor receptor in the mammalian cells by Salmonella typhimurium. Nature 1992, 357:588-589.

32. Cuervo P, Mesquita-Rodrigues C, D'avila Levy CM, Britto C, Pires FA, Gredilha $R$, Alves $C R$, Jesus JB: Serine protease activities in Oxysarcodexia thornax (Walker) (Diptera: Sarcophagidae) first instar larva. Mem Inst Oswaldo Cruz 2008, 103:504-506.

33. Mesquita-Rodrigues C, Saboia-Vahia L, Cuervo P, Masini d'Avila Levy C, Alves-Honório N, Domont GB, De Jesus JB: Expression of Trypsin-like serine peptidases in pré-imaginal stages of Aedes aegypti (Diptera: Culicidae). Arch Insect Biochem Physiol 2011, 76:223-235.

34. Terra WR, Ferreira C, Jordão BP, Dillon RJ: Digestive enzymes. In Biology of the Insect Midgut. London: Chapman and Hall; 1996.

35. Reeck G, Oppert B, Denton M, Kanost M, Baker JE, Kramer KJ: Insect proteinases. In Proteases: New Perspectives. Basel, Boston, Berlin: Birkhauser Verlag; 1999:125-148.

36. Venancio TM, Cristofoletti PT, Ferreira C, Verjovski-Almeida S, Terra WR: The Aedes aegypti larval transcriptome: a comparative perspective with emphasis on trypsins and the domain structure of peritrophins. Insect Mol Biol 2009, 18:33-44.

37. Bozic N, Dojnov B, Milovanovic A, Nenadovic V, Ivanovic J, Vujcic Z: Characterization of endopeptidases from the midgut of Morimus funereus (Coleoptera:Cerambycidae) larvae. Arch Biol Sci Belgrade 2008, 60:403-409.

38. Muharsini S, Sukarsih, Riding G, Partoutomo S, Hamilton S, Willadsen P, Wijffels G: Identification and characterisation of the excreted/secreted serine proteases of larvae of the old world screwworm fly, Chrysomya bezziana. Int J Parasitol 2000, 30:705-714.

39. Budatha M, Meur G, Dutta-Gupta A: Identification and characterization of midgut proteases in Achaea janata and their implications. Biotechnol Lett 2008, 30:305-310.

40. Vinokurov KS, Elpidina EN, Oppert B, Prabhakar S, Zhuzhikov DP, Dunaevsky YE, Belozersky MA: Fractionation of digestive proteinases from Tenebrio molitor (Coleoptera:Tenebrionidae) larvae and role in protein digestion. Comp Biochem Physiol B 2006, 145:138-146.

41. Brito LO, Lopes AR, Parra JRP, Terra W, Silva-Filho MC: Adaptation of tobacco budworm Heliothis virescens to proteinase inhibitors may be mediated by the synthesis of new proteinases. Comp Biochem Physiol $B$ 2001, 128:365-375

42. Oppert B, Walters $P$, Zuercher M: Digestive proteinases of the larger black flour beetle, Cynaeus angustus (Coleoptera: Tenebrionidae). Bull Entomol Res 2006, 96:167-172.

43. Zdobnov EM, von Mering C, Letunic I, Torrents D, Suyama M, Copley RR: Comparative genome and proteome analysis of Anopheles gambiae and Drosophila melanogaster. Science 2002, 298:149-159.

44. Fazito-do-Vale V, Pereira MH, Gontijo NF: Midgut pH profile and protein digestion in the larvae of Lutzomyia longipalpis (Diptera: Psychodidae). J Insect Physiol 2007, 53:1151-1159.

45. Chen PS, Briegel H: Studies on the protein metabolism of Culex pipiens $\mathrm{L}$ Changes in free amino acids and peptides during embryonic development. Comp Biochem Physiol 1965, 14:463-473.

46. Cho WL, Deitsch KW, Raikhel AS: An extraovarian protein accumulated in mosquito oocytes is a carboxypeptidase activated in embryos. Proc Nat Acad Sci U S A 1991, 88:10821-10824.

47. Izumi S, Yano K, Yamamoto Y, Takahashi SY: Yolk proteins from insect eggs: Structure, biosynthesis and programmed degradation during embryogenesis. J Insect Physiol 1994, 40:735-746.

48. Gomes FM, Oliveira DM, Motta LS, Ramos IB, Miranda KM, Machado EA: Inorganic polyphosphate inhibits an aspartic protease-like activity in the eggs of Rhodnius prolixus (Stahl) and impairs yolk mobilization in vitro. J Cell Physiol 2010, 222:606-611.

49. Young A, Meeusen EN, Mancuso N, Bowles VM: Proteases released by Lucilia cuprina during egg hatch. Insect Biochem Mol Biol 1997, 27:1017-1026.

50. Young A, Meeusen EN, Mancuso N, Bowles VM: Characterisation of proteases involved in egg hatching of the sheep blowfly, Lucilia cuprina. Int J Parasit 2000, 30:925-932
51. Yang YJ, Davies D: Trypsin and chymotrypsin during metamorphosis in Aedes aegypti and properties of the chymotrypsin. J Insect Physiol 1971, 17:117-131.

52. Ho BC, Khoo HG, Chew LM, Wong KP, Ewert A: Food ingestion and digestive enzymes in larval Aedes aegypti and Aedes albopictus (Diptera: Culicidae). J Med Entomol 1992, 29:960-964.

53. Nauen R, Sorge D, Sterner A, Borovsky D: TMOF-like factor controls the biosynthesis ofserine proteases in the larval gut of Heliothis virescens. Arch Insect Biochem Physiol 2001, 47:169-180.

54. Espinoza-Fuentes FP, Ribeiro AF, Terra WR: Microvillar and secreted digestive enzymes from Musca domestica larvae. Subcellular fractionation of midgut cells with electron microscopy monitoring. Insect Biochem 1987, 17:819-827.

55. Lemos FJA, Terra WR: A high yield preparations of Musca domestica larval midgut microvilli and subcellular distribution of amylase and trypsin. Insect Biochem Mol Biol 1992, 22:433-438.

56. Angulo-Valadez CE, Cepeda-Palacios R, Ascencio F, Jacquiet P, Dorchies P, Romero MJ, Khelifa RM: Proteolytic activity in salivary gland products of sheep bot fly (Oestrus ovis) larvae. Vet Parasitol 2007, 149:117-125.

57. Elpidina EN, Tsybina TA, Dunaevsky YE, Belozersky MA, Zhuzhikov DP, Oppert B: A chymotrypsin-like proteinase from the midgut of Tenebrio molitor larvae. Biochimie 2005, 87:771-779.

58. Tsybina TA, Dunaevsky YE, Belozersky MA, Zhuzhikov DP, Oppert B, Elpidina EN: Digestive proteinases of yellow mealworm (Tenebrio molitor) larvae: purification and characterization of a trypsin-like proteinase. Biochemistry (Mosc) 2005, 70:300-305.

doi:10.1186/1756-3305-5-123

Cite this article as: Borges-Veloso et al:: Proteolytic profiling and comparative analyses of active trypsin-like serine peptidases in preimaginal stages of Culex quinquefasciatus. Parasites \& Vectors 2012 5:123.

\section{Submit your next manuscript to BioMed Central and take full advantage of:}

- Convenient online submission

- Thorough peer review

- No space constraints or color figure charges

- Immediate publication on acceptance

- Inclusion in PubMed, CAS, Scopus and Google Scholar

- Research which is freely available for redistribution 